\title{
Challenges that Global Governance Currently Confronts to Ensure More Secure, Prosperous and Democratic World
}

\section{Mikheil Shavtvaladze}

Mikheil Shavtvaladze, 36, is a graduate who received his Master's of Arts degree in Political Science at the Central European University in 2010. His written Master Thesis was on the post-soviet transitions and conflict resolution. Currently, he is a PbD student, visiting lecturer and AFP Returning Scholar at the Tbilisi State University's Faculty of Social and Political Science. His interests include comparative politics, international relations, democratization and state building, modernization and development, conflict resolution, foreign policy analysis, etc.

\begin{abstract}
The study intends to explore what those emerging challenges are that global governance presently deals with on its attempts to guarantee more secure, prosperous and democratic world. For that reason, the cases for each specific emerging regional threat have been selected and analyzed. The conclusion drawn from the analysis shows the major deficiencies found in the contemporary system of global governance which can be attributed to the systems incapacity to address these problems with more concerted and coordinated global approach.
\end{abstract}

Keywords: Conflict resolution; Debt trap; Democratic peace; Global governance; Security. 


\section{Introduction: the current stage of global governance}

The growing threats that our planet currently faces mainly in forms of repressive regimes, violent conflicts, human rights abuses, poverty, pandemics and environmental hazards, as never before, "require a concerted and coordinated global approach" (Griffits, O'Callaghen and Roach 2008). For that reason, the existing system of global governance needs to be enhanced in a way to respond more efficiently those emerging challenges, implications of which transcends far beyond a nation-state.

Despite the existing or emerging global powers such as the United States, the European Union, the BRICS, together with the numerous multilateral institutions such as the UN and NATO, attempting "to manage relations between states and to facilitate cooperative action across various issue-areas" (Griffits, O'Callaghen and Roach 2008, 127), no supranational global government yet exists to be able to take immediate and more effective measures against those above mentioned security concerns.

Consequently, citizens around the globe face with dilemma what kind of governing mechanism to rely on to ensure better democratic stability inside and outside of the countries in which they inhabit. Besides, another important issue deserving close attention is how to create such system in a way to ensure its legitimacy and equality.

Pondering nowadays about the creation of the global constitution can still sound as a quite distant futuristic project. Portraying, however, the current state of international system as a mere anarchical also misses the point and distorts the changing reality that now exists.

Hence, it can be presumed that thanks to the all-encompassing and accelerating globalization processes that humankind currently experiences, the modern system of global governance can be better described "as a half-way house between the international anarchy underlying Realist analysis and world state." (Weiss 2013)

It should be acknowledged that despite some converging tendencies taking place in the current structure of global governance, the system still lacks accountability and legitimacy to act in collective manner. First of all, the global governance so far is heavily constrained by national borders, laws, rules and norms. Second of all, because of sharp disparities among the countries around the world in distribution of the political-economic powers, not every country has the same share and weight in the global governance's decision-making.

Finally, albeit "governance is carried out in the name of the global polity by both governmental and non-governmental organizations" (Griffits, O'Callaghen and Roach 2008, 127) the contemporary system of "global governance lacks fundamental dimensions of constitutional and hence democratic accountability." (Davis 2012,4) 
Considering the above mentioned problems, in this conference paper, firstly I would like to explore what those emerging challenges are that global governance confronts these days to ensure more secure world. Secondly, I want to find out those existing economic challenges that global governance urges to address at present so as to facilitate more economically prosperous world. Finally, I aim to discuss the challenges that current global governance are encountering on its way to promote more democratic and legitimate world order.

\section{Global implications of regionally emerged security threats: violent conflicts}

Recently ignited violent civic upheavals in places as Ukraine, Syria, Thailand and Venezuela, as well as the unresolved ethno-territorial conflicts in the South Caucasus, point to the fact that "the contemporary system of global governance" (Weiss 2013) fails to avert and resolve quickly and efficiently such security threats that emerge foremost at the regional level.

Even though, the violent civil conflicts for the most part are confined within borders of a particular state, their implications to global security often turn out to be critical. Hence, in order to understand how civil conflicts initially emerged at the regional level transform into a problem with a global dimension, several serious concerns can be highlighted.

First of all, in such conflicts, main participants or actors "in a given state often are linked in various ways to actors in other states." (Billon 2009, 596) Second of all, a "conflict in one state may spread and foster violence in other states as well as generate conflict between nation states.” (Billon 2009) Lastly, the extremely aggressive civil clashes affect other states, including neighboring countries, "through externalities of conflict such as refugees" (Billon 2009), transnational crime and "economic impact." (Billon 2009)

Explanations of such incapacity to efficiently respond the above mentioned challenges can be many, calling for deeper and further examinations of this topic. For example, one of the main explanations can be ascribed to the institutional deficiencies of governances in a country level itself relating to its corrupted, undemocratic and unstable regimes.

However, this section of the paper focuses on global governance today and its failure to address these problems with more efficiency. Consequently, it can be argued that the global governance's failure to resolve the above mentioned security threats can be mainly attributed to "the lack of authoritative institutions with truly global reach." (Davis 2012, 276)

\section{Violent civil upheavals: the Ukrainian revolution}

The recent violent street clashes that Ukraine has experienced, leading to "dozens of people dead and hundreds more injured as protestors fought police in the capital, Kiev" (Prodi 
2014), points to the fact that failure to prevent violent civil upheaval promptly causes its further deterioration with wider ramifications and consequences.

Although the most blame to precipitate such violent strife in that case falls on the proRussian Viktor Yanukovych led government provoking it firstly by "not signing a trade and association agreement with the EU" (Bershidsky 2014), secondly not "to call an early elections" (Bershidsky 2014) that could have sent protesters home, and thirdly resorting to violence to disperse activists, it should be emphasized that the contemporary global system of governance responsible for managing this type of security threats, failed either to prevent this clash from becoming even more deadly and chaotic.

Regardless of international efforts "aimed at ending a lethal spiral of violence in Ukraine" (Higgins and Kramer 2014) resulting in a "hard-fought accord" (Higgins and Kramer 2014) between the pro-European opposition leaders and pro-Russian President Yanukovych that "lasted less than a day" (Shevtsova 2014), the global approaches intended to resolve the conflict seemed far from concerted and coordinated one.

Instead what we witnessed resembles to a zero-sum "geopolitical struggle between Russia and the West" (Higgins and Kramer 2014) over spheres of influence in Ukraine. Hence, as the case of Ukraine shows, due to the sharp internal divide, mutual distrust and winner-take-all approaches characterizing major participants of the modern system of global governance, the system appears to be incapable to address such security threats in more competent way.

\section{Violent intra and interstate conflicts: the Georgia's post-Soviet wars}

Similar to Ukraine, Georgia, another post-Soviet state but located in the South Caucasus, has also suffered from several violent internal conflicts since its independence. However, apart from atrocious civil clashes and coups, Georgia fought two ethno-territorial wars with its autonomous republics of Abkhazia and South Ossetia in the early 90s.

Yet, due to the unsuccessful attempts to resolve these "frozen" conflicts, the military interstate conflict between Georgia and Russia had ensued over the breakaway autonomous republic South Ossetia in the August 2008. As in the case of Ukraine, the conflict resolution approaches of the global powers supposed to end the Georgia's post-Soviet conflicts turned into "the clash of alternative regional projects: that of Russia's would-be sphere of influence with that of an ever enlarging sphere of democracy, security and prosperity as promoted by the EU and US.” (Makarychev 2011, 79)

Whatever internal and external "multiple causes and many contributing factors" (Crocker, Hampson and Aall 2009, 493) leading to these conflicts, in this particular chapter, I 
want to emphasize the limits of the contemporary global governing system to successfully manage the above mentioned emerging security threats with large-scale repercussions.

The mounting discord between Georgia and Russia over the issues as the breakaway regions of Abkhazia and South Ossetia, the Russia's interest to reassert its influence in the region, the Georgia's Euro-Atlantic drive added with “the Bush administration's unequivocal backing to President Saakashvili" (Bowker 2011, 12) and ill-thought, arbitrary and aggressive rhetoric towards Russia espoused at that time by President Saakashvili and his associates, led the tensions to descend further into bitter hostilities between two post-Soviet states.

Such rapidly progressing hostilities between the countries culminated into the war resulting in 850 casualties from both sides "not to mention those who were wounded, who went missing, or the far more 100000 civilians who fled their homes." (Tagliavini 2009, 6) Speaking of the wider implications of the war, apart from the military fight between "the Russian and Georgian armies, it was also a clash of ambition and vision between Russia, the US and the EU." (Makarychev 2011, 79)

Moreover, the August 2008 war demonstrated how important Georgia is for the Europe's energy security because of Georgia's geostrategic role of being transit route for energy resources flowing from the Caspian basin (Jones 2013, 345) to Europe. Furthermore, it pointed to the fact that politically unstable Georgia threatens not only the country's internal security but also Europe's. Consequently, the unresolved ethno-territorial conflicts further exacerbate problems associated with refugees, criminality, illegal arms and drug trafficking.

However, despite "the cease-fire agreement negotiated by the European Union on 12 August 2008" (Bowker 2011, 2), overall, the conflict exposed serious constraints of the contemporary system of global governance to avert such emerging challenges efficiently.

With regard to specific shortcomings in the existing global structure to counter successfully the emergence of the intra and interstate violent conflicts, the case of Georgia revealed several of them. First of all, "the war exposed the West's inability to prevent Russia from moving aggressively to restore its primacy over the former Soviet territory." (Sarikaia 2011)

For example, the chain of events as the recognition of Kosovo's independence on February 2008, weak international reactions to the atrocities in Chechnya, refusal to grant Georgia NATO's Membership Action Plan in April 2008, contributed to the Russia's aggressive moves towards Georgia. (Jones 2013, 345)

Besides, despite of the United Nations (UN) and the Organization for Security and Cooperation in Europe (OSCE)'s eighteen year long involvement in the peace processes in the breakaway region of the South Ossetia, these multilateral institutions, largely due to their 
uncoordinated efforts and modus operandi, ensured Russian peacekeepers, under the mandate of the Commonwealth of Independent States (CIS), to be the only peacekeeping force to be presented on the ground. (Jones 2013, 337)

However, it is important to note that such outcome was the result of the Russia's permanent membership into the UN's Security Council, empowering Russia to veto any internationally proposed peace initiative. (Jones 2013, 337) In addition, Russia’s continuing violation of Georgia's territoriality and sovereignty was not followed with subsequent international sanctions pointing to the notion that compared to the conflicts in Balkans, the West showed less interest towards the conflicts in Georgia. (Jones 2013, 345)

Concluding this section that discussed specifically the limits of global governance with regard to resolve successfully violent ethno-territorial conflicts, particularly in the post-Soviet Georgia, it can be observed that "great power mismanagement -or - 'cacophony' instead of a 'concert' - may be regarded as a symptom of the international society dysfunctions" (Makarychev $2011,78)$ leading to military conflicts.

\section{Global implications of regionally emerged economic threats: recessions and inequalities}

Since the stability and security of any system, whether local or global, largely depends on its level of economic development and equality, it can be assumed that severe recessions and inequalities can seriously undermine system and even lead to its ultimate collapse. Besides, it can be claimed that implications inflicted by recessions and inequalities can go beyond borders of any nation-state by becoming a problem with worldwide magnitude.

Moreover, "there is broad consensus that poverty constitutes the leading risk factor for conflicts." (Billon 2009, 210) For example, "major interstate conflicts such as the Second World War, often took place following protracted economic recessions" (Billon 2009, 212). Furthermore, as the analysis on the recent world protests shows, 843 protests occurred "between January 2006 and July 2013 in 87 countries covering over 90\% of world population.” (Ortiz, et al. 2013, 5)

Apart from deep recessions, another important economic and societal challenge in front of global society today is inequalities, which, among many things, are precipitated also by uneven economic growth, corruption and market externalities (e.g. monopolies, cartels etc). For instance, as we have witnessed recently "the Occupy movements which began in Wall Street and then spread elsewhere" (Weiss 2013) was clear manifestation of growing "distaste for inequalities within industrialized countries as well as worldwide." (Weiss 2013) 
Accordingly, this part of paper discusses those locally emerging economic concerns such as recessions and inequalities which effects extend much further than a country's economic system causing as well global instability and insecurity.

\section{Recessions: the Greece's debt crisis}

When the global "financial and economic crises of 2008" (Ortiz, et al. 2013, 8) wreaked havoc on the entire world's financial system, not only developing but also the Eurozone member countries such as Greece, Spain, Italy and Portugal fell victims of massive bailouts and austerity measures that "exacerbated pre-existing concerns about poverty, unemployment and rising inequality." (Ortiz, et al. 2013, 8)

As a result, Greece, a member of the EU and Eurozone, hit badly by these circumstances plunged deeper into debt and recession spiral. Apart from domestic causes of this emerging Greece's debt crisis, mostly associated with elite corruption and government's inefficient economic policies, the major external factor was the country's heavy "dependence on wider European and Atlantic economic structures.” (Fouskas 2013, 133)

It is important to note that dramatic increase of a country's debt ratio, especially external debt, with regard to Gross Domestic Product (GDP) might lead a nation-state downwards to the debt trap, "a situation in which a state has to spend much of its earnings from trade on servicing its external debts rather on economic and social development." (Griffits, O'Callaghen and Roach 2008, 61)

Thus, the consequences inflicted by such crises turns to be grave both domestically, and globally. Speaking of domestic impact, the Greece's debt crisis "brought the country to the brink of economic collapse" (Sotiropouls 2012, 23). For example, over the five-year long recession, in 2013, the Greece's GDP emerged "20 percent lower than in 2008, unemployment at 26 percent and one in three people living on or below the poverty line" (Fouskas 2013, 132). Moreover, the Greece's debt ratio to GDP amounted to 180 percent.

Apart from devastating economic impact on the country, the economic crisis in Greece revealed internal societal dangers such as "disintegration of middle class", "sociopolitical polarization" and the rise of "the extreme-right Golden Down party with 16 percent of national vote" (Fouskas 2013, 137).

As to the economic crisis's international repercussions, if Greece has to "exit from Eurozone" due to "debtor-led default" (Fouskas 2013, 137) " it could not only bring about the end of Eurozone but damage the entire geo-political balance of power in NATO” (Fouskas 
2013, 138). Besides, leaving the Eurozone "would also gravely affect other EU national economies" (Sotiropouls 2012, 34) and "the exchange value of the Euro" (Sotiropouls 2012, 34).

For that reason, facing with much more complex and highly interrelated world, further concerted and consolidated global governance by "governments and international organizations is needed, in order to manage problems initially believed to be negligible, such as the crisis in Greece" (Sotiropouls 2012, 35).

\section{Global implications of regionally emerged political threats: political inequality and intolerance}

What kind of global governing system would be emerged from the world with still so many undemocratic states around? Since sovereign states "for foreseeable future" (Weiss 2013) remain "the fundamental units of the system" (Weiss 2013) "political inequality at home translates into political inequality on the global stage" (Dubrow 2013, 65).

As the latest study on world protests shows, a large number protests that took place between 2006 and 2013 resulted "not for economic justice per se, but for what prevents economic issues from being addressed: a lack of real democracy" (Ortiz, et al. 2013, 6). For example, other than Ukraine, the most recent anti-government protests flared up in such different parts of the world as Venezuela and Thailand.

It is noteworthy to mention that, akin to Ukraine, both these protest actions turn out to be deadly for the citizens of these countries. In Venezuela's case, during the protest that started on February 12 2014, demonstrators among security and economic related issues also demanded "protected freedom of speech" (Shoichet, Mullen and Bothelo 2014). Whereas in Thailand, demonstrators called for resignation of Prime Minister Yingluck Shinawarta alleging her in corruption deals.

While the political stability and peace in the world should be among major goals of the contemporary system of globally governance, the above evidences show clearly that only through genuine democratic political systems, as at domestic as well as at global level, are these goals attainable. As Kofi A. Annan wrote in his article "democratic rulers cannot mobilize their countries for war without convincing most citizens that war is both just and necessary" (Annan 2002, 138).

Therefore, in general, wars and conflicts, according to the "Democratic Peace" (Griffits, O'Callaghen and Roach 2008, 67) theory, are less likely within democratic system since disagreements aroused locally or internationally "are resolved through compromise and negotiation rather than conflict and coercion" (Griffits, O'Callaghen and Roach 2008, 67). 
For that reason, this section of the paper tries to analyze the locally emerged political threats such as political inequality and intolerance that present great challenges for the existing system of global governance to secure more democratic and legitimate world order.

\section{Political inequality and intolerance: the Syrian turmoil}

Reflecting on the violent crisis in Syria, evoked by the Arab Spring and "caused over 100 000 deaths and more than two million refugees" (Hussain 2013, 39), it can be presumed how the behaviors of authoritarian regimes, manifested in political violence and repressions directed towards their dissents, could turn a local political dynamics "into regional rivalry and global threat" (Hussain 2013, 39).

Despite "a landmark agreement on 14 September between John Kerry and Russian Foreign Ministry Sergei Lavrov" (Hussain 2013, 47) on peacefully solution of the crisis last year, there is a risk that the "shaky peace deal" (Hussain 2013, 47) still might not succeed leading to forceful and military resolution of "the Syrian conundrum" (C. Crocker 2013, 16).

Failure of the existing global governing system to manage the Syrian crisis timely and efficiently, and what is most important without so much bloodshed and destruction, further exemplifies the limits of the current international community to deal with such locally emerged political crises with more combined and synchronized global approach.

In short, this particular crisis revealed sharp internal divide within those global and regional actors interested in solving this issue and also exposed "another dangerous development" (Hussain 2013, 48) namely "the incapacitation of the United Nations to act in global affairs in the light of global rivalry and divisions in the UN Security Council” (Hussain 2013, 48).

\section{Conclusion}

The major purpose of the paper is to uncover those crucial regionally originated security, economic and political challenges that often convert into global threats and require joint and organized global approach from the contemporary system of global governance in order to avoid their further exacerbation. For that intention, I embarked on analyzing the cases for each particular regionally or locally emerged danger.

While examining the global implications of the regionally erupted security menaces such as violent civil and ethno-territorial conflicts, I invoked cases of the Ukraine's recent revolution and the Georgia's post-Soviet wars. Concerning global influences of the locally emerged economic problems, I draw an example from the Greece's latest debt crisis. Finally, I discussed 
the recent Syrian crisis in relation with a global impact of regionally or locally mounted political hazards as the political inequality and intolerance are.

Based on the subsequent observations and analysis of this study, it can be deduced that major deficiencies in the ability of the existing system of global governance to peacefully, efficiently and timely resolve the aforementioned growing security, economic and political challenges can be mainly related to the systems' incapacity, resulting largely from its sharp internal divide and mismanagement, to act in a more unified and coordinated way. 


\section{References}

Annan, Kofi A. "Democracy as an International Issue." Global Governance, 2002: 135-142.

Bershidsky, Leonid. "OpEd: Bershidsky: The West could have prevented bloodshed in Ukraine." Newsday Web site. February 19, 2014.

http://www.newsday.com/opinion/oped/bershidsky-the-west-could-have-prevented-

bloodshed-in-ukraine-1.7134664 (accessed February 20, 2014).

Billon, Philippe Le. "Economic and Resource Causes of Conflict." In The SAGE Handbook of Conflict Resolution, by Jacob Bercovitch, Viktor Kremenyuk and William I. Zartman, 210-224.

Los Angeles, London, New Delhi, Singapore, Wachington DC: SAGE, 2009.

Bowker, Mike. "The War in Georgia and the Western Response." Central Asian Survey, 2011: 197-211.

Crocker, Chester A., Fen Oslen Hampson, and Pamela Aall. "Why Mediation Matters: Ending Intractable Conflicts." In The SAGE Handbook of Conflict Resolution, by Jacob Bercovitch, Victor Kremenyuk and William Zartman, 493-505. Los Angeles, London, New Delhi, Singapore, Washington DC: SAGE, 2009.

Crocker, Chester. "Syria's Crisis of Transition." The National Interest, 2013: 16-24.

Davis, James W. "A Critical View of Global Governance." Swiss Political Science Review, 2012: 272-286.

Dubrow, Joshua Kjerulf. "Democratic Global Governance, Political Inequality, and the Nationalist Retrenchment Hypothesis." International Journal of Sociology , 2013: 55-69.

Fouskas, Vassilis K. "Whatever Happened to Greece?" The Political Quartery, 2013: 132-138.

Griffits, Martin, Terry O'Callaghen, and Steven C. Roach. International Relations: The Key Concepts. London and New York: Routledge, 2008.

Higgins, Andrew, and Andrew E. Kramer. "Europe: Ukraine Has Deal, but Both Russia and Protesters Appear Wary." The New Yorks Times Web site. February 21, 2014. http://www.nytimes.com/2014/02/22/world/europe/ukraine.html? r=1 (accessed February 22, 2014).

Hussain, Nazir. "The Syrian Crisis and Regional Order in the Middle East." Pakistan Horizon, 2013: 39-51.

Jones, Stepen. Georgia: A Political History since Independence . Tbilisi: Center for Social Sciences, 2013.

Makarychev, Andrey. "Chapter 4: Russia and NATO After the Georgia War: Re-Actualizing the Great Power Managment Prospects." In The Great Power (mis) Managment: The RussianGeorgian War and its Implications for Global Political Order, by Alexander Astrov, 59-79. Farnham, Surrey: ASHGATE, 2011. 
Ortiz, Isabel, Sara Burke, Mohamed Berrada, and Hernan Cortes. World Protests 2006-2013. Working Paper, New York: Initiative for Policy Dialogue; Friedrich-Ebert-Stiftung, 2013.

Prodi, Romano. "The Opinion Pages: How Ukraine Can Be Saved." The New York Times Web site. February 20, 2014.

http://www.nytimes.com/2014/02/21/opinion/prodi-how-ukraine-can-be-saved.html? $r=0$ (accessed February 20, 2014).

Sarikaia, Yalcin. "Georgian Foreign Policy After the August 2008 War." Journal of Black Sea Studies, 2011: 1-16.

Shevtsova, Lilia. "Eurasia Outlook: Ukraine: How to Cross the Valley of Tears." Carnegie Moscow Center. February 25, 2014.

http://www.carnegie.ru/eurasiaoutlook/?fa $=54637$ (accessed February 25, 2014).

Shoichet, Catherine E., Jethro Mullen, and Greg Bothelo. "From flames to fiery opposition, protests rock Ukraine, Venezuela, Thailand." CNN Web site. February 18, 2014.

http://edition.cnn.com/2014/02/18/world/world-protests-

explainer/index.html?iid=article sidebar (accessed February 19, 2014).

Sotiropouls, Dimitri A. "The Political Causes and Consequences of the Economic Crisis in Greece, 2010 - 2012." Hellenic Studies, 2012: 23-37.

Tagliavini, Heidi. Volume I: Independent International Fact-Finding Mission on the Conflict in Georgia. Independent International Fact-Finding Mission on the Conflict in Georgia, Official Journal of the European Union, 2009, 1-49.

Weiss, Thomas G. Global Governance: Why What Whither. Malden: Polity Press, 2013. 